\title{
Inhibition of Human Cytochrome P450 Metabolism by Blended Herbal Products and Vitamins
}

\author{
Teresa W Tam ${ }^{1}$, Humayoun Akhtar ${ }^{2}$, John Thor Arnason ${ }^{1}$, Kosta Cvijovic ${ }^{3}$, Heather Boon ${ }^{3}$, D William Cameron ${ }^{4}$, Cathy E \\ Drouin $^{1}$, Walter Jaeger ${ }^{5}$, Ross T Tsuyuki ${ }^{6}$, Sunita Vohra ${ }^{7}$, and Brian C Foster ${ }^{1,8}$ \\ ${ }^{1}$ Centre for Research in Biopharmaceuticals and Biotechnology, University of Ottawa, Ottawa, ON, Canada \\ ${ }^{2}$ Guelph Food Research Centre, Agriculture and Agri-Food Canada, Guelph, ON, Canada \\ ${ }^{3}$ Leslie Dan Faculty of Pharmacy, University of Toronto, Toronto, ON, Canada \\ ${ }^{4}$ Faculty of Medicine, Univeristy of Ottawa, Ottawa, ON, Canada \\ ${ }^{5}$ Department of Clinical Pharmacy and Diagnostics, University of Vienna, Vienna, Austria \\ ${ }^{6}$ Faculty of Medicine and Dentistry, University of Alberta, Edmonton, AB, Canada \\ ${ }^{7}$ CARE Program, Faculty of Medicine and School of Public Health, University of Alberta, Edmonton, AB, Canada \\ ${ }^{8}$ Office of Science, Therapeutic Products Directorate, Health Canada, Ottawa, ON, Canada
}

Received, September 29, 2010; Revised, November 16, 2010; Accepted November 26, 2010; Published January 1, 2011.

\begin{abstract}
Purpose. The use of supplements as herbal and micronutrient natural health products with conventional health products has become increasingly popular. It has been reported that some herbal products can inhibit the activity of cytochrome P450-mediated metabolism and drug disposition. This study was designed to investigate a case report of a severe adverse event to determine the potential interactions of two blended botanical products and vitamins on cytochrome P450-mediated drug metabolism. Methods. The effect of extracts from these commercially available herbal formulations, trans- $\beta$-carotene (tBC), multivitamins, and vitamin $\mathrm{D}_{3}$ supplements on cytochrome $\mathrm{P} 450$-mediated drug metabolism of marker substrates was determined in vitro. Results. The two blended herbal products had a high potential to affect the safety and efficacy of many health products. Some vitamin and tBC containing products also have the potential to affect drug disposition. The $\mathrm{tBC}$ content of various products was analyzed and significant discrepancies were found among them and between values indicated on product labels. Product extracts also exhibited a low to moderate capacity to inhibit cytochrome P450 2C9, 2C19 and 3A4-mediated metabolism. Conclusions. The findings of this study suggest that these herbal products and most vitamin products may have an inhibitory effect on cytochrome P450 activity that could contribute to development of an adverse event. Further work is warranted to determine how supplementation with these products may affect drug metabolism in an in vivo context.
\end{abstract}

\section{INTRODUCTION}

Natural health products (NHPs), including traditional Chinese medicines, homeopathic remedies, vitamins, minerals and trace elements, herbal remedies, probiotics, amino acids, plant isolates and essential fatty acids are popular complementary or alternative medicine (CAM) therapies. NHPs are frequently used by patients with chronic or recurrent conditions; these patients are also the most likely to be prescribed conventional medications on an ongoing basis (1$5)$. Although the risk of adverse events (AEs) from drug-NHP interactions is widely reported (6-13), there are relatively few reported NHP-related AEs with the approximately 45,000 NHPs marketed for use in Canada alone (14-15). Currently, AEs associated with NHPs are generally monitored through a passive surveillance system based entirely on voluntary reporting by health professionals or consumers. There is a staggering under-reporting of potential NHP-related AEs as opposed to their lack of occurrence (14). In the survey of community pharmacists, the findings revealed that almost half (47\%) of 132 responding pharmacists had seen a potential NHP-drug interaction, but only two (1.5\%) reports were filed (15).

As pharmacists routinely inquire about medication use and recognize AEs, a partnership with community pharmacies was established to conduct a pilot Study Of Natural health product $A$ dverse Reactions (SONAR) to assess the

Corresponding Author: Dr. BC Foster, Health Canada, Therapeutic Products Directorate, Holland Cross Tower B, AL:3102C3, 1600 Scott Street, Ottawa, ON, Canada;

Email: brian.foster@hc-sc.gc.ca 
feasibility of utilizing active surveillance in participating community pharmacies to identify AEs related to concurrent NHP-prescription drug use. In a preliminary evaluation of the active surveillance case reports, four cases were noted that warranted an in-depth evaluation. The one commonality in these case reports was that all individuals used vitamins concurrently with their health products. Multi-vitamins were identified in 3 cases and a calcium-vitamin D supplement in the fourth. Case Report: In the most serious case report, a 38 year old, $140 \mathrm{lb}, 5^{\prime} 6^{\prime \prime}$ female patient with an aboriginal-Caucasian ethnicity having a hormone disorder experienced an adverse event with fatigue, nervousness, heart palpitation, rash, and muscle twitching. At the onset of the event, the patient had started taking femMED (NRP 410) 4 times daily (Q.I.D., Table 1). Prior to the event, she had been taking a multivitamin with green tea extract twice daily for about 1 year and a $100 \mathrm{mg}$ progesterone cream (compounded in the pharmacy; actual applied dose unknown) once daily for about 5 months. Her naturopath suggested that she may have reacted badly to scullcap and wild yam in the NRP 410 product and was started on Thyrosense (NRP 409), Q.I.D. The adverse events continued and only stopped when all the herbal medications were discontinued at the direction of her physician. She experienced a positive rechallenge. The patient experienced similar AEs when consuming a cup of green tea some time after stopping the herbal medications. NRP 409 and 410 are blended multiconstituent products (Table 2) with limited information on the potential of either the blended product or individual botanical constituents to cause cytochrome P450-mediated interactions. These findings are consistent with our earlier in vitro study suggesting that there may be interactions between vitamins and other medicinal products (16).

Vitamins are naturally occurring organic substances that are not synthesized in the body and supplements are taken as a complementary dietary source (17). There are 13 essential vitamins with 3 or more present in multivitamin products. Carotenoid compounds are naturally occurring in orange fruits and vegetables, green vegetables, and in algae. Trans- $\beta$-carotene (tBC), an isoprenoid compound is metabolized by a two step process through retinal to form retinol (vitamin A), and it can be further oxidized to retinoic acid (18-19). Vitamin D3 has to be enzymatically transformed into the biologically active form 1,25dihydroxyvitamin D3 (DD3) (20-21). CYP2C11, $27 \mathrm{~A} 1,2 \mathrm{D} 25,2 \mathrm{R} 1,3 \mathrm{~A} 4$, and $2 \mathrm{~J} 3$ are known to catalyze vitamin D metabolism (21). tBC and DD3 can modulate gene expression of CYP3A (22-25); tBC can also modulate MDR1 (24). Expression of CYP3A4 can be induced through different nuclear receptors such as the pregnane $\mathrm{X}$ receptor (PXR), the constitutive androstane receptor (CAR) and the vitamin D receptor (VDR) (24). VDR binds to and mediates the effects of the DD3 to alter gene transcription (22).

In a single-center longitudinal study with 14 healthy Caucasian adult volunteers ( 7 men, 7 women) self-administered vitamin C $500 \mathrm{mg}$ twice/day for 14 days, no significant effect of vitamin C on CYP3A4 activity was observed (26). However, sex and baseline results were significant predictors of changes in CYP3A4 activity as in men, the mean activity increased by $21.9 \%(95 \%$ confidence interval $-3.88-47.6 \%)$. The effect in women was not consistent. In a separate 7-day study with 7 healthy male subjects, $1000 \mathrm{mg}$ /day vitamin $\mathrm{C}$ significantly decreased the $\mathrm{AUC}_{0-8 \mathrm{hr}}$ and Cmax of indinavir IND (27). The Cmin was $32 \%$ lower in the presence of vitamin $\mathrm{C}$ suggesting that high doses of vitamin $\mathrm{C}$ can reduce steady-state indinavir plasma concentrations.

This study was undertaken to evaluate if there was a metabolic mechanism underlying the adverse events noted in the case report. The potential for NRP 409 and 410 to modulate the activity of CYP3A4, a known metabolic enzyme of progesterone, and other $\mathrm{P} 450$-mediated metabolism was examined together with extracts from 8 transB-carotene products, 10 multivitamins, and 2 vitamin $\mathrm{D}_{3}$ supplements (Table 1). Authentic standards of tBC derivatives were also examined by observing their interaction with human cytochrome $\mathrm{P} 450$ isozymes.

\section{METHODS}

Human ethics review board approval was obtained in order to collect information on natural health product and drug interactions, and then to conduct interviews with willing individuals and their physician(s). 


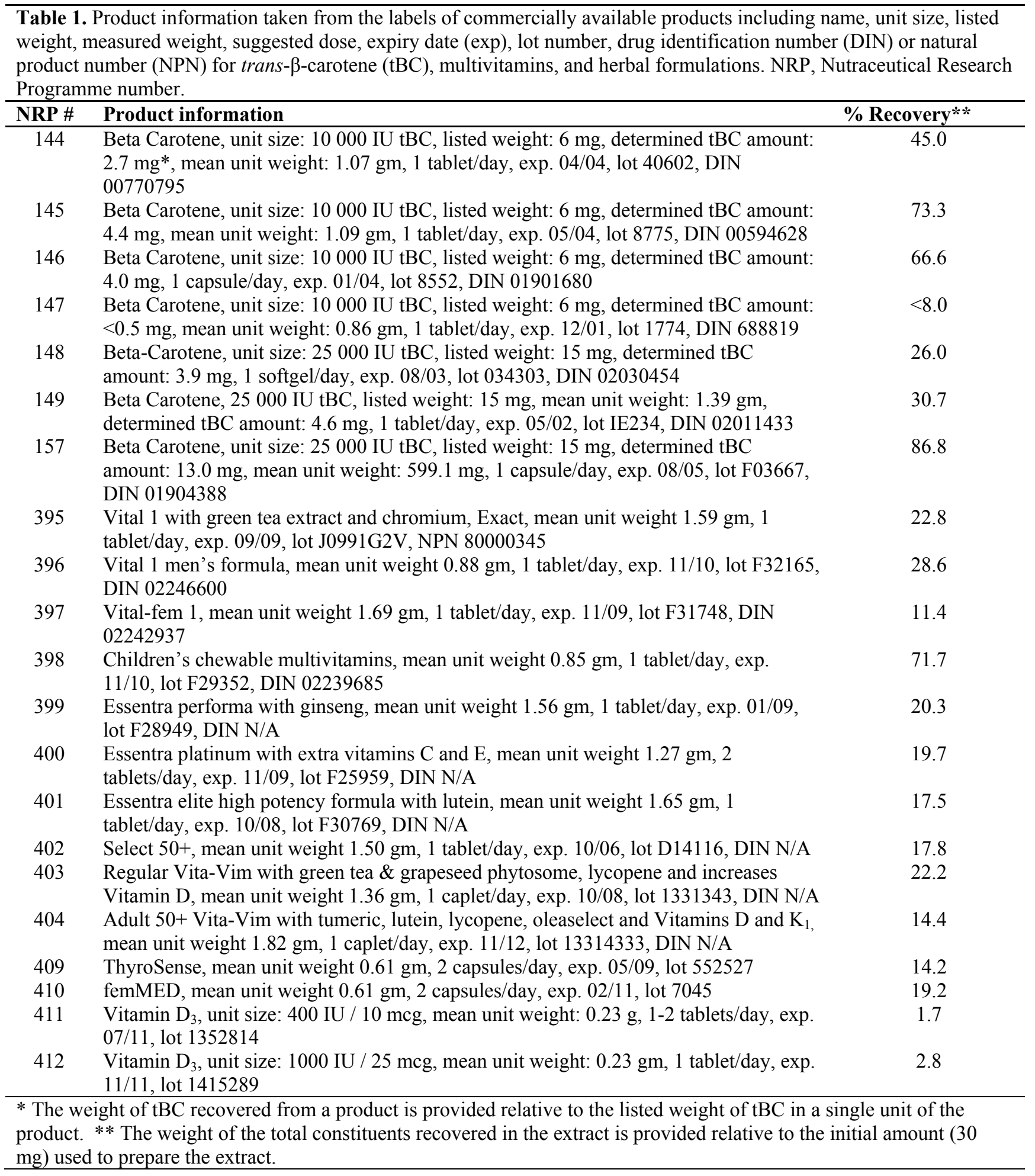

\section{Substrates and Reference Compounds}

Thyrosense, femMED, multi-vitamins, transcarotene (tBC), and vitamin $\mathrm{D}_{3}$ were obtained from local outlets (Table 1). They were selected to give a representation of the local market. These products were assigned unique identifying Nutraceutical
Research Programme (NRP) accession numbers, and product vouchers were stored in the herbarium at the University of Ottawa. Tablets and caplets were finely ground with a mortar and pestle. All products were tested within their expiry date. 
Table 2. Summary of the components of two blended botanical products (NRP 409) and (NRP 410) listed on the product labels. All amounts are listed in mg. NRP, Nutraceutical Research Programme number. -, absent, x present but the amount not listed.

\begin{tabular}{lcc}
\hline INGREDIENT & $\mathbf{4 0 9}$ & $\mathbf{4 1 0}$ \\
\hline $\begin{array}{l}\text { Ashwagandha (Withania somnifera) extract; 1.5\% } \\
\text { withanolides (5:1 from 750 mg Ashwagandha) }\end{array}$ & 150 & - \\
Guggul (Commiphora mukul) extract; 2.5\% & & - \\
guggulsterones (3:1 from 360 mg Guggul) & 120 & 200 \\
Saw Palmetto (Serenoa repens berry) & & 100 \\
Chastetree Berry (Vitex agnus-castus) & - & 50 \\
Milk Thistle (Silybum marianum seed) & - & 50 \\
Scullcap (Scutellaria lateriflora herb) & - & 50 \\
Red Raspberry (Rubus idaues leaf extract, 4:1) & - & 50 \\
Wild Yam (Dioscorea composite root) & - & - \\
Copper & - & - \\
Iodine & 0.500 & - \\
L-Tyrosine & 0.100 & - \\
Manganese & 500 & - \\
Pantothenic acid & 0.500 & $\mathrm{x}$ \\
Cellulose & 100 & $\mathrm{x}$ \\
Microcrystalline cellulose & $\mathrm{x}$ & - \\
Purified water & $\mathrm{x}$ & - \\
Rice starch & $\mathrm{x}$ & - \\
Silicon dioxide & $\mathrm{x}$ & $\mathrm{x}$ \\
Vegetable grade magnesium stearate & $\mathrm{x}$ & $\mathrm{x}$ \\
Water & $\mathrm{x}$ & $0.61(0)$ \\
Avg. weight in g ( \pm SD); $\mathrm{n}=5$ & - & \\
\hline
\end{tabular}

Table 3. Summary of $\beta$-carotene content and excipient components listed on the product labels of the different supplements examined in this study. NRP, Nutraceutical Research Programme number, - absent, $x$ present but the amount not listed.

\begin{tabular}{|c|c|c|c|c|c|c|c|}
\hline Ingredient & NRP 144§ & NRP $145 \S$ & NRP 146§ & NRP 147§ & $\begin{array}{l}\text { NRP } \\
148\end{array}$ & NRP 149§ & $\begin{array}{l}\text { NRP } \\
157\end{array}$ \\
\hline $\begin{array}{l}\text { MEDICINAL } \\
\beta \text {-carotene }\end{array}$ & $10,000 \mathrm{IU}$ & $10,000 \mathrm{IU}$ & $10,000 \mathrm{IU}$ & $10,000 \mathrm{IU}$ & $25,000 \mathrm{IU}$ & $25,000 \mathrm{IU}$ & $25,000 \mathrm{IU}$ \\
\hline \multicolumn{8}{|l|}{ NON-MEDICINAL } \\
\hline Beeswax & & & & & - & & $\mathrm{x}$ \\
\hline Gelatin & & & & & $\mathrm{x}$ & & $\mathrm{x}$ \\
\hline Glycerin & & & & & $\mathrm{x}$ & & $\mathrm{x}$ \\
\hline Hydrogenated soybean oil & & & & & - & & $\mathrm{x}$ \\
\hline Purified water & & & & & $\mathrm{x}$ & & $\mathrm{x}$ \\
\hline Soybean oil & & & & & - & & $\mathrm{x}$ \\
\hline Soy lecithin & & & & & - & & $\mathrm{x}$ \\
\hline Vegetable oil shortening & & & & & - & & $\mathrm{x}$ \\
\hline $\begin{array}{l}\text { Avg. weight in } \mathrm{mg} \text { ( } \pm \\
\text { SD); } \mathrm{n}=5\end{array}$ & $440(0)$ & $450(0.01)$ & $380(0.01)$ & $290(0)$ & $270(0.01)$ & $760(0.01)$ & $250(0)$ \\
\hline
\end{tabular}


Table 4. Summary of vitamin, mineral, and excipient components listed on the product labels of the multivitamin supplements (Nutraceutical Research Programme numbers 395 to 404). All amounts are listed in mg unless otherwise indicated. -, absent; $\mathrm{x}$, present but amount not listed. Supplemental information is appended at the end.

\begin{tabular}{|c|c|c|c|c|c|c|c|c|c|c|}
\hline Ingredient & 395 & 396 & 397 & 398 & 399 & 400 & 401 & 402 & $403 \S$ & $404 \S$ \\
\hline \multicolumn{11}{|l|}{ VITAMIN } \\
\hline \multirow[t]{2}{*}{ Vitamin A } & - & 4000 & $4000 \mathrm{IU}$ & 2500 & 1000 & $500 \mathrm{IU}$ & 1000 & 1000 & 3000 & 2000 \\
\hline & & IU & & IU & IU & & $\mathrm{IU}$ & $\mathrm{IU}$ & IU & $\mathrm{IU}$ \\
\hline Vitamin $B_{1}$ & 1.9 & 2.25 & 1.5 & 1.05 & 4.5 & 1.15 & 2.25 & 2.25 & 2.5 & 2.25 \\
\hline Vitamin $B_{2}$ & 2.1 & 2.55 & 1.7 & 1.2 & 5.1 & 1.6 & 3.2 & 3.2 & 2.5 & 3.2 \\
\hline Vitamin $\mathrm{B}_{6}$ & 2.5 & 3 & 2 & 1.05 & 6 & 5 & 8 & 8 & 25 & 8 \\
\hline Vitamin $\mathrm{B}_{12}$ & 0.0075 & 0.009 & 0.006 & 0.0045 & 0.02 & 0.0125 & 0.025 & 0.025 & 0.025 & 0.025 \\
\hline Vitamin C & 60 & 90 & 60 & 60 & 120 & 125 & 90 & 90 & 150 & 90 \\
\hline Vitamin $D_{3}$ & $400 \mathrm{IU}$ & $400 \mathrm{IU}$ & $400 \mathrm{IU}$ & $400 \mathrm{IU}$ & $400 \mathrm{IU}$ & $200 \mathrm{IU}$ & $400 \mathrm{IU}$ & $600 \mathrm{IU}$ & $600 \mathrm{IU}$ & $800 \mathrm{IU}$ \\
\hline Vitamin E & $30 \mathrm{IU}$ & $45 \mathrm{IU}$ & $30 \mathrm{IU}$ & $15 \mathrm{IU}$ & $60 \mathrm{IU}$ & $100 \mathrm{IU}$ & $75 \mathrm{IU}$ & $75 \mathrm{IU}$ & $15 \mathrm{IU}$ & $40 \mathrm{IU}$ \\
\hline \multirow[t]{2}{*}{ B-Carotene } & 2500 & 1000 & $4050 \mathrm{IU}$ & - & 2000 & 5000 & 3000 & 3000 & 2000 & 6000 \\
\hline & IU & IU & & & IU & IU & IU & IU & IU & IU \\
\hline Biotin & - & - & - & - & 0.04 & 0.0225 & 0.045 & 0.045 & 0.015 & 0.045 \\
\hline Folic Acid & 0.4 & 0.4 & 0.4 & 0.3 & 0.6 & 0.35 & 0.6 & 0.6 & 0.4 & 0.6 \\
\hline Niacinamide & 25 & 20 & 20 & 13.5 & 15 & 7.5 & 15 & 15 & - & 35 \\
\hline $\begin{array}{l}\text { Pantothenic } \\
\text { Acid }\end{array}$ & 12.5 & 10 & 10 & - & 10 & 5 & 10 & 10 & - & 10 \\
\hline Vitamin K & - & - & - & - & - & - & - & 0.025 & - & 0.08 \\
\hline Ave & 2.01 & 3.69 & 5.68 & 1.98 & 2.40 & 3.94 & 3.05 & 3.18 & 3.84 & 5.96 \\
\hline \multicolumn{11}{|l|}{$\begin{array}{l}\text { Vitamin/mg } \\
\text { unit weight }\end{array}$} \\
\hline \multicolumn{11}{|l|}{ MINERAL } \\
\hline Calcium & 300 & - & 450 & - & 162 & 87.5 & 200 & 200 & 150 & 200 \\
\hline Chlorine & - & 34 & - & - & 80 & - & - & - & - & - \\
\hline Chromium & 0.15 & 0.15 & - & - & 0.025 & 0.0125 & 0.1 & 0.1 & 0.001 & 0.1 \\
\hline Copper & 2 & 2 & - & - & 1.4 & - & 2 & 1 & 1 & 2 \\
\hline Iodine & - & 0.15 & - & - & 0.15 & 0.075 & 0.15 & 0.15 & 0.1 & 0.1 \\
\hline Iron & 14 & - & 27 & - & 8 & 5 & 4 & 4 & 4 & - \\
\hline Lutein & - & - & - & - & - & 0.25 & 0.25 & - & $0.3^{*}$ & $0.3^{*}$ \\
\hline Magnesium & 50 & 100 & - & - & 50 & 2.5 & 50 & 50 & 75 & 50 \\
\hline Manganese & 2 & 3.3 & - & - & 4 & - & 5 & 5 & - & 5 \\
\hline Molybedum & - & 0.0417 & - & - & 0.05 & 0.0125 & 0.025 & 0.045 & - & 0.025 \\
\hline Nickel & - & - & - & - & 0.005 & 0.0025 & 0.005 & - & - & 0.005 \\
\hline Phosphorus & - & - & - & - & 125 & 62.5 & 125 & - & - & 125 \\
\hline Potassium & - & 0.0375 & - & - & 72 & 20 & 80 & 80 & - & 80 \\
\hline Selenium & 0.07 & 0.0875 & - & - & 0.055 & 0.0125 & 0.025 & 0.055 & 0.001 & 0.025 \\
\hline Silicon & - & - & - & - & 0.01 & 0.005 & 0.01 & - & - & 0.001 \\
\hline Tin & - & - & - & - & 0.01 & 0.05 & 0.01 & - & - & 0.001 \\
\hline Vanadium & - & - & - & - & 0.001 & 0.005 & 0.001 & - & - & 0.001 \\
\hline Zinc & 0.015 & 15 & 15 & - & 10 & 7.5 & 15 & 7.5 & 10 & 15 \\
\hline $\begin{array}{l}\text { Avg. weight } \\
(\mathrm{mg} \pm \mathrm{SD}) \\
\mathrm{n}=5\end{array}$ & $\begin{array}{l}1509 \\
(0.01)\end{array}$ & $\begin{array}{l}880 \\
(0.02)\end{array}$ & $\begin{array}{l}1690 \\
(0.01)\end{array}$ & $\begin{array}{l}850 \\
(0.02)\end{array}$ & $\begin{array}{l}1560 \\
(0.02)\end{array}$ & $\begin{array}{l}1270 \\
(0)\end{array}$ & $\begin{array}{l}1650 \\
(0.01)\end{array}$ & $\begin{array}{l}1500 \\
(0.01)\end{array}$ & $\begin{array}{l}1306 \\
(0.02)\end{array}$ & $\begin{array}{l}1820 \\
(0.01)\end{array}$ \\
\hline
\end{tabular}

Authentic tBC, nictotinamide adenine dinucleotide phosphate reduced form (NADPH), retinol (ROL), retinal (RAL), retinoic acid (RTE), tranylcypromine, quinidine, bifonazole, and verapamil were purchased from Sigma-Aldrich (Oakville, ON, Canada). 3-Cyano-7- 
ethoxycoumarin (CEC), dibenzylfluorescein (DBF), 7-methoxy-4-(trifluoromethyl)-coumarin (MFC), AMMC, microsomes derived from Baculovirus infected insect cells expressing CYP2C19, 2D6, $3 \mathrm{~A} 4,3 \mathrm{~A} 7$ or 19 were purchased from $\mathrm{BD}$ Biosciences (Mississauga, ON, Canada). Ketoconazole was purchased from Calbiochem (Gibbstown, NJ, USA). All other chemicals and solvents were of analytical grade.

For the tBC studies, extracts were prepared from $100 \mathrm{mg} / \mathrm{mL}$ ground $\mathrm{tBC}$ material in acetonitrile, ethanol, methanol, or water by sonication and vortexing for $1 \mathrm{~min}$. The extract was separated from the undissolved material by centrifugation for $18 \mathrm{~min}$ at $13,000 \mathrm{rpm}$. For the multi-vitamin and herbal formulation studies, a similar procedure was followed, but the extracts were prepared from $30 \mathrm{mg} / \mathrm{ml}$ in methanol. For the vitamin $\mathrm{D}_{3}$ studies, the extracts were prepared from $50 \mathrm{mg} / \mathrm{ml}$ in methanol. Liquid tBC capsules were emptied into a $1.5 \mathrm{~mL}$ microfuge tube and 3 volumes of $55 \%$ ethanol was added. The solution was vortexed and centrifuged for $18 \mathrm{~min}$ at 13,000 rpm. All samples were stored at $-20^{\circ} \mathrm{C}$, kept protected from light, and were freshly prepared daily.

\section{Carotene Biomarker Analysis}

Ground tBC tablets (100 $\mathrm{mg})$ were mixed thoroughly with $10 \mathrm{~mL}$ of butanol, centrifuged, and filtered. The process was repeated once more. A $200 \mu \mathrm{L}$ was withdrawn from this combined butanol stock solution and diluted with $2 \mathrm{~mL}$ of butanol for a total volume of $2.2 \mathrm{~mL}$. After a brief mixing, and centrifugation at $3,500 \mathrm{x} \mathrm{g}$ for $15 \mathrm{~min}, 20 \mu \mathrm{L}$ of the clear solution was analyzed for $\mathrm{tBC}$ content.

Gelatin capsules containing tBC were weighed (approx. $380 \mathrm{mg}$ ) and a careful incision was made in each to avoid the loss of material. The capsules were placed in a container with $15 \mathrm{~mL}$ butanol, and then stirred for $15 \mathrm{~min}$ at a moderate speed. The liquid content was decanted into a centrifuge tube, and the residue was re-extracted with the same volume of butanol. The combined butanol (dark red and heavily turbid) extract was vortexed briefly, centrifuged at $3,500 \times \mathrm{g}$ for $30 \mathrm{~min}$, and $200 \mu \mathrm{L}$ of the clear solution was diluted with $2 \mathrm{~mL}$ butanol and analyzed.

\section{HPLC Analysis of B-carotene}

An Agilent Model 1100 Series equipped with a photodiode array detector and a degasser was used to separate, identify and quantify ß-carotenes in tablets and capsules. Separation was carried out on a $5 \mu \mathrm{m}$ Phenomenex Primesphere C-18 reversed phase HPLC column (250 $\mathrm{mm} \times 4.6 \mathrm{~mm}$ ID) protected with a $\mathrm{C}-18$ guard column. The mobile phase consisted of solvent A: acetonitrile:methanol:dichloromethane $\quad(60: 30: 10$ $\mathrm{v} / \mathrm{v} / \mathrm{v})$ and solvent B: acetonitrile:methanol:dichloromethane $\quad(50: 30: 20$ $\mathrm{v} / \mathrm{v} / \mathrm{v}$ ) at a flow rate of $1 \mathrm{~mL}$ per min. The sample injection volume was $20 \mu \mathrm{L}$, and components were eluted starting with $100 \%$ solvent $\mathrm{A}$ and reaching $100 \%$ solvent B in $20 \mathrm{~min}$. The spectra were run at $450 \mathrm{~nm}$. Under these conditions $\beta$-carotene and $\alpha-$ carotene had a retention time of $15.6 \mathrm{~min}$ and 16.2 min (small peak), respectively. Concentration of tBC was calculated by comparison to a calibration curve of authentic material.

\section{Cytochrome P450 Assay}

Aliquots of extract solutions were screened for their ability to inhibit CYP2C9, 2C19, 2D6, 3A4, 3A5 or $3 \mathrm{~A} 7$ marker substrates using an in vitro fluorometric assay in clear-bottom, opaque-welled microtiter plates (96 well, Corning Costar, model \# CSOO-3632, Corning, NY). For the tBC and multivitamin/vitamin $\mathrm{D}_{3} /$ herbal formulation studies, $3 \mu \mathrm{L}$ and $2 \mu \mathrm{L}$ of extract were tested, respectively. The assay procedure was reported previously (28-29). All control, control-blank, test and test-blank wells were balanced to contain an equal volume of methanol or water present in the extracts; no well contained more than $1 \%$ of the solvent vehicle. All wells had $0.6 \mathrm{mM}$ NADPH; substrate $(0.12 \mu \mathrm{M}$ AMMC - 2D6; $25 \mu \mathrm{M}$ CEC - 2C19; $1 \mu \mathrm{M}$ DBF $3 \mathrm{~A} 4 / 5 / 7,19 ; 100 \mu \mathrm{M} \mathrm{MFC}-2 \mathrm{C} 9)$ with or without test sample. However, only $0.3 \mathrm{mM} \mathrm{NADPH}$ was required to maintain linear reaction conditions in the CYP2D6 assay. Control and test wells contained active isozyme (70 nM 2C9, $20 \mathrm{nM} 2 \mathrm{C} 19,10 \mathrm{nM}$ 2D6, 3A4/5/7, 19) in phosphate buffer $\left(\mathrm{KH}_{2} \mathrm{PO}_{4}\right.$, $\mathrm{pH} 7.4,0.2 \mathrm{M}$ ), whereas isozyme denatured by boiling for $15 \mathrm{~min}$ was added to the control-blank and test-blank wells. The positive inhibitors used were $75 \mu \mathrm{M}$ tranylcypromine (CYP2C19), $2 \mu \mathrm{M}$ quinidine (CYP2D6), $1 \mu \mathrm{M}$ ketoconazole (CYP3A4, 3A7), and $0.4 \mu \mathrm{M}$ bifonazole (CYP19). All isozymes were stored at $-80^{\circ} \mathrm{C}$ until used and 
were not subjected to more than 2 freeze-thaw cycles. Isozymes were rapidly thawed in a $37^{\circ} \mathrm{C}$ sand bath and mixed gently with the substrate solution prior to addition. The microwell plates were incubated $20-60 \mathrm{~min}$ at $37^{\circ} \mathrm{C}$ depending upon the isozyme, and the final fluorescence was measured using a Cytofluor 4000 Fluorescence Measurement System.

All samples were prepared in triplicate with the resultant percent inhibition calculations based on the mathematical combinations for the differences in fluorescence between the test/test-blank wells and the mean difference between each control and blank well. Controls were run with every assay. Each assay was repeated at least once. As a cell-free assay where a $20-25 \%$ coefficiency of variation may occur, negative values indicating a high level of substrate biotransformation are not indicative of induction but represent inherent biological variation of the assay. All assays were performed with indate material under gold fluorescent lighting or reduced lighting.

\section{RESULTS}

\section{Samples and Constituents}

Twenty one vitamin samples were examined in this study (Table 1). The active medicinal ingredients and non-medicinal excipients for the $\mathrm{tBC}$, multivitamin and vitamin $\mathrm{D}_{3}$ products are listed in Tables 3 to 5 , respectively. There are differences in the content of medicinal constituents and excipients between the vitamin products. The percent recovery of the total non-soluble suspended solid constituents in the extracts of all products was examined (Table 1). Total percent recovery for the 7 different tBC products (NRP 144-149, 157) was not determined as HPLC analysis for the total amount of tBC present was undertaken. These extracts had levels $13.2 \%$ to $92.0 \%$ less tBC than the amount specified on the product labels (Table 1). Most of the tBC products contained between 4 to $5 \mathrm{mg}$ tBC per tablet, except for NRP 144 and 147 which contained much less tBC. NRP 157 had the highest amount of $\mathrm{tBC}$ detected with $13 \mathrm{mg} \mathrm{tBC}$ per tablet. The percent recovery from the multivitamin samples (NRPs 395 to 404 ) ranged from $11.4 \%$ to $28.6 \%$ for most products except the chewable vitamin NRP 398 which had a $71.7 \%$ recovery. The lowest recoveries were with the vitamin D3 products NRP 411 and 412 at 1.7 to $2.8 \%$. NRP 409 and NRP 410 had an average recovery of 14.2 and $19.2 \%$, respectively.

\section{trans-B-Carotene}

The potential for $\mathrm{tBC}$ product extracts to affect cytochrome P450-mediated metabolism of marker substrate by three different isozymes (CYP3A4, $2 \mathrm{C} 19$, and 2C9) in vitro was examined in two stages. In the first stage the $\mathrm{tBC}$ products underwent an initial screening for CYP inhibition using 100 $\mathrm{mg} / \mathrm{ml}$ stock extracts. The tBC extracts were more inhibitory towards CYP2C9 and 2C19 with ranges of $65.2 \%$ to $86.2 \%$ inhibition (Table 6 ). The tBC extracts were less inhibitory towards CYP3A4 and inhibited with ranges $12.6 \%$ to $73.3 \%$ of CYP3A4 activity.

Table 5. Summary of the components of the vitamin $\mathrm{D}_{3}$ supplements (NRP 411 and 412) listed on the product labels. All amounts are listed in mg unless otherwise indicated. -, absent; $x$, present. NRP, Nutraceutical Research Programme number.

\begin{tabular}{lcc}
\hline Ingredient & NRP 411 & NRP 412 \\
\hline Vitamin $\mathrm{D}_{3}$ (Cholecalciferol) & $10 \mathrm{mcg} / 400 \mathrm{IU}$ & $25 \mathrm{mcg} / 1000 \mathrm{IU}$ \\
NON-MEDICINAL & & $\mathrm{X}$ \\
Cellulose & $\mathrm{X}$ & $\mathrm{X}$ \\
& $\mathrm{X}$ & - \\
Dicalcium phosphate & $\mathrm{X}$ & $\mathrm{X}$ \\
Modified cellulose gum & $\mathrm{X}$ & $230(0.01)$ \\
Vegetable magnesium stearate & $230(0.01)$ & \\
Avg. weight in mg $( \pm$ SD); $\mathrm{n}=5$ & & \\
\hline
\end{tabular}


Table 6. The percent inhibition of the cytochrome P450-mediated metabolism of substrates by various trans- $\beta$-carotene product extracts $(100 \mathrm{mg} / \mathrm{ml}$ stock extracts). Mean $\pm \mathrm{SD}$ of at least two separate tests. NRP, Nutraceutical Research Programme number. ND, not determined.

\begin{tabular}{lccc}
\hline NRP \# & 2C9 & 2C19 & 3A4 \\
\hline $\mathbf{1 4 4}$ & $74.6 \pm 6.2$ & $80.7 \pm 7.5$ & $59.3 \pm 1.5$ \\
$\mathbf{1 4 5}$ & $\mathrm{ND}$ & $79.4 \pm 4.8$ & $\mathrm{ND}$ \\
$\mathbf{1 4 6}$ (aqueous layer) & $80.4 \pm 2.2$ & $69.0 \pm 0.7$ & $73.1 \pm 4.7$ \\
$\mathbf{1 4 6}$ (oily layer) & $77.0 \pm 4.9$ & $65.2 \pm 1.3$ & $45.8 \pm 1.7$ \\
$\mathbf{1 4 7}$ & $70.4 \pm 0.7$ & $85.4 \pm 2.7$ & $73.3 \pm 3.7$ \\
$\mathbf{1 4 8}$ (aqueous layer) & $77.6 \pm 0.5$ & $86.2 \pm 3.1$ & $34.6 \pm 3.6$ \\
$\mathbf{1 4 8}$ (oily layer) & $73.8 \pm 1.8$ & $69.2 \pm 2.3$ & $47.0 \pm 1.4$ \\
$\mathbf{1 4 9}$ & $66.4 \pm 0.6$ & $85.1 \pm 7.0$ & $59.3 \pm 2.6$ \\
$\mathbf{1 5 7}$ & $\mathrm{ND}$ & $\mathrm{ND}$ & $12.6 \pm 2.6$ \\
\hline
\end{tabular}

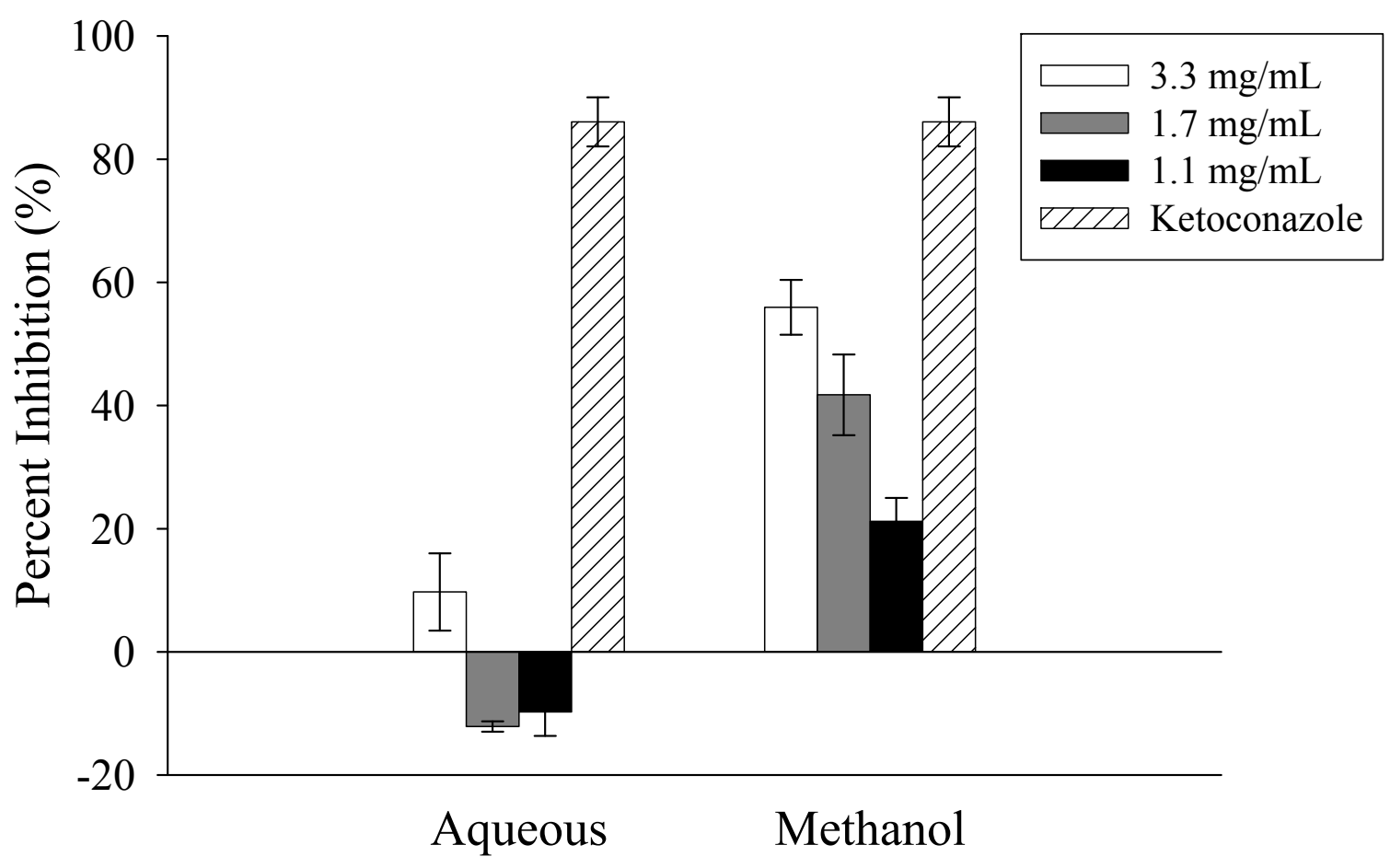

Figure 1. Effect of aqueous and methanolic extracts from trans- $\beta$-carotene (NRP 157) on the cytochrome P450 3A7mediated metabolism of dibenzylfluorescein relative to ketoconazole $(0.5 \mu \mathrm{g} / \mathrm{ml})$. Mean $\pm \mathrm{SD}$ of at least two separate tests. NRP, Nutraceutical Research Programme number.

There was no discernable relationship between tBC content (Table 1) and the inhibitory effect. In fact, NRP 147, whose tBC content was less that $500 \mu \mathrm{g}$ per tablet was found to be highly inhibitory (70$85 \%$ ) towards the three isozymes. There was little variability in the ability of either layer to inhibit CYP-mediated metabolism.

In the second study, the effect of aqueous and methanolic extracts of NRP 157 on the in vitro metabolism of DBF by CYP3A4, 3A5 and 3A7 was examined. Neither aqueous and methanol extracts at the three concentrations inhibited CYP3A4 or CYP3A5 metabolism (results not shown). The methanol extracts had a dose-dependant inhibitory effect on CYP 3A7 (Figure 1). Only the highest concentration aqueous extract had an inhibitory effect. 
The potential for authentic $\mathrm{tBC}$ and 3 derivative standards to mediate biotransformation was examined in four isozymes (Table 7). The 4 compounds had similar inhibitory marked activity towards CYP2C9 and 2C19 with less affect on CYP3A4. All 4 had markedly less activity towards CYP2D6-mediated metabolism. The retinoic acid had the least activity in this in vitro assay.

Degradation products of retinol were not detected in NRP 157. At times a small shoulder appeared which could be attributed to cis- $\beta$ carotene and/or $\alpha$-carotene (results not shown). There was initially a considerable variation in the values of $\beta$-carotene in NRP 156 as the tablets had large number of flakes requiring the samples to be finely ground. There was also variation in capsules, but within acceptable limits.

\section{Multivitamins and Vitamin $D_{3}$}

A comparative evaluation of aqueous and methanolic extracts found that the methanolic extracts consistently resulted in the highest inhibitory effects. The 10 multivitamins and the 2 vitamin $\mathrm{D}_{3}$ products were examined for their ability to inhibit CYP2C19-, 2D6-, 3A4-, 3A7-, and 19mediated metabolism using methanolic extracts (Table 8). Of the 12 extracts examined, 9 had a negative inhibitory effect towards CYP2C19 activity. Three products, NRP 395, 396, and 399 had an inhibitory range of $43 \%$ to $77.2 \%$. Most of the extracts had a weak or negative inhibitory effect towards CYP2D6 activity. The most inhibitory product was NRP 295 which inhibited $25.2 \%$ of CYP2D6 activity. Similar results were observed for CYP3A4 and 3A7 and inhibition from the products ranged from $3.7 \%$ to $69.4 \%$. The extracts had a weak or negative inhibitory effect towards CYP19 activity which ranged from $-8.2 \%$ to $23.7 \%$. Three of the multivitamin products, NRP 395, 396, and 399 were generally more inhibitory towards the CYPs isozymes. Both NRP 395 and 399 contained the herbal components, green tea and ginseng, respectively (Table 4 ). The vitamin $\mathrm{D}_{3}$ products had a very weak or negative inhibitory effect towards all 5 CYP isozymes examined.

Table 7. The percent inhibition of cytochrome P450-mediated metabolism by trans- 3 -carotene, retinol, retinal, and retinoic acid in $100 \%$ ethanol $(1 \mathrm{mg} / \mathrm{ml}$ stock extracts $)$. Mean $\pm \mathrm{SD}$ of at least two separate tests. NRP, Nutraceutical Research Programme number.

\begin{tabular}{lcccc}
\hline & CYP2C9 & CYP2C19 & CYP2D6 & CYP3A4 \\
\hline trans-B-carotene & $66.0 \pm 4.2$ & $68.2 \pm 3.3$ & $9.8 \pm 1.2$ & $38.1 \pm 2.8$ \\
retinol & $76.7 \pm 0.4$ & $78.5 \pm 5.6$ & $2.4 \pm 1.3$ & $77.1 \pm 9.9$ \\
retinal & $84.0 \pm 5.0$ & $79.2 \pm 1.5$ & $21.2 \pm 1.9$ & $25.9 \pm 11.6$ \\
retinoic acid & $57.6 \pm 3.3$ & $45.7 \pm 9.6$ & $7.6 \pm 0.6$ & $27.2 \pm 1.1$ \\
\hline
\end{tabular}

Table 8. The percent inhibition of the cytochrome P450-mediated metabolism of substrates by various multivitamin ( 30 $\mathrm{mg}$ ground material $/ \mathrm{ml}$ ) and vitamin $\mathrm{D}_{3}$ products $(50 \mathrm{mg}$ ground material $/ \mathrm{ml}$ ) stock methanol extracts respectively). Mean \pm SD of at least two separate tests. NRP, Nutraceutical Research Programme number.

\begin{tabular}{cccccc}
\hline NRP \# & 2C19 & 2D6 & 3A4 & 3A7 & 19 \\
\hline $\mathbf{3 9 5}$ & $43.8 \pm 2.9$ & $25.2 \pm 1.3$ & $46.7 \pm 5.8$ & $69.4 \pm 3.2$ & $23.7 \pm 0.7$ \\
$\mathbf{3 9 6}$ & $77.2 \pm 2.2$ & $-4.6 \pm 1.1$ & $50.6 \pm 7.1$ & $37.6 \pm 1.1$ & $20.9 \pm 0.4$ \\
$\mathbf{3 9 7}$ & $-7.4 \pm 12.3$ & $-15.3 \pm 3.8$ & $20.5 \pm 8.5$ & $25.1 \pm 5.7$ & $7.9 \pm 4.4$ \\
$\mathbf{3 9 8}$ & $-14.0 \pm 1.2$ & $-15.1 \pm 5.5$ & $12.9 \pm 4.1$ & $18.3 \pm 1.5$ & $-0.9 \pm 4.5$ \\
$\mathbf{3 9 9}$ & $55.8 \pm 7.8$ & $0.5 \pm 1.5$ & $29.5 \pm 7.0$ & $35.9 \pm 14.9$ & $22.2 \pm 0.1$ \\
$\mathbf{4 0 0}$ & $-20.2 \pm 15.0$ & $-11.8 \pm 2.5$ & $12.7 \pm 7.4$ & $18.6 \pm 0.1$ & $0.9 \pm 2.5$ \\
$\mathbf{4 0 1}$ & $-29.7 \pm 13.7$ & $-9.3 \pm 0.3$ & $10.4 \pm 8.6$ & $14.0 \pm 1.9$ & $-8.2 \pm 4.7$ \\
$\mathbf{4 0 2}$ & $-23.4 \pm 3.0$ & $-8.9 \pm 2.2$ & $20.8 \pm 2.5$ & $22.5 \pm 4.9$ & $7.7 \pm 2.0$ \\
$\mathbf{4 0 3}$ & $-11.8 \pm 12.2$ & $17.8 \pm 1.1$ & $13.2 \pm 7.7$ & $29.4 \pm 0.4$ & $12.1 \pm 3.8$ \\
$\mathbf{4 0 4}$ & $-0.3 \pm 5.8$ & $9.3 \pm 0.2$ & $23.7 \pm 4.9$ & $18.3 \pm 0.1$ & $3.2 \pm 2.2$ \\
$\mathbf{4 1 1}$ & $-2.2 \pm 1.5$ & $-9.6 \pm 0.2$ & $6.0 \pm 2.0$ & $5.7 \pm 0.1$ & $9.1 \pm 0.6$ \\
$\mathbf{4 1 2}$ & $10.7 \pm 0.4$ & $-5.1 \pm 3.5$ & $12.5 \pm 1.3$ & $3.7 \pm 3.9$ & $13.1 \pm 3.1$ \\
Positive Inhibitor & $91.2 \pm 0.7$ & $88.7 \pm 0.2$ & $89.5 \pm 0.2$ & $54.7 \pm 0.0$ & $74.1 \pm 2.6$ \\
\hline
\end{tabular}




\section{Herbal Formulations}

Two herbal formulation products associated with the case report, NRP 409 and NRP 410 were examined for their ability to inhibit CYP2C19-, 2D6-, 3A4-, 3A7-, and 19-mediated metabolism using aqueous and methanolic extracts. Marked differences in inhibition towards the different isozymes were observed, as well as the inhibitory potential between aqueous and methanolic extracts. The methanolic extract was more inhibitory than the aqueous extract for NRP 409 for the 5 isozymes examined (Figure 2A). CYP2D6-mediated metabolism was the least inhibited. The methanolic extract inhibited all of the other isozymes with greater than $62.6 \%$ inhibition. The activities of CYP2C19, 3A4 and 3A7 were inhibited by the methanolic extract by greater than $94.1 \%$ relative to the vehicle control. The aqueous extract inhibited the majority of the isozymes with approximately half the potency as the methanolic extract. The greatest variance was observed with the aqueous extract inhibition of $21.5 \%$ as compared to methanolic $95.0 \%$ inhibition of CYP3A4 activity.

As with NRP 409, the methanolic extract of NRP 410 was more inhibitory than the aqueous extract for all of the isozymes except with CYP2D6 (Figure 2B). The difference in CYP2D6 inhibition was substantial, as the aqueous extract inhibited $75.8 \%$ of CYP2D6 activity, but the methanolic extract inhibited only $1.1 \%$. A great difference in inhibition between the extracts was also observed for CYP3A4, as the aqueous extract had no inhibition towards the isozyme, but the methanolic extract completely inhibited the isozyme relative to the vehicle control. Both extracts affected CYP19mediated metabolism with similar weak potencies.

\section{DISCUSSION}

In this study, the effect of an extract of a constant weight of ground material to inhibit biotransformation was compared between commercially available products. The findings demonstrated that the inhibitory values for NRP 147 with very low levels of tBC were similar to those with the highest content, NRP 157. Even in studies where the same amount of tBC was constant between samples (data not reported), the inhibitory potential could not be correlated to the $\mathrm{tBC}$ content of the samples. It is also noteworthy that in the soft gel products (NRP 146 and 148) marked inhibitory activity was present in the two distinct layers obtained following centrifugation. These findings suggest that the inhibitory potential of these samples resides in multiple substances which could include potential degradative products or excipients. The inhibitory potential of the vitamins is modest. The potential of the different vitamin products examined in this study to affect CYP-mediated metabolism is consistent with our earlier study (16) and that of other NHPs (30-34).

The study of authentic reference compounds on their inhibitory effect on CYP2C9-, CYP2C19-, CYP2D6-, and CYP3A4-mediated suggests that the derivatives have a higher inhibitory effect on the metabolism of these isozymes. The low recovery of tBC in the commercial products was unexpected, as was the subsequent determination that retinoic acid derivatives were not detected.

The AEs, noted in the case report where the female patient with hormone disorder treated with a topical progesterone cream and a multivitamin product after supplementing her therapy with NRP 410 , could be attributed to a number of factors such as; adulteration with a therapeutic product, an allergic response to one of the components, an interaction with one or more of the components or concomitant medications or non-medicinal excipients, or an unrelated cause of event mistakenly associated with these medications.

The rechallenge response can eliminate the last factor that this was a mistaken association. An allergy seems unlikely as the response was noted separately with green tea as the components in this tea are less likely to be presented in either of the 2 NHPs associated with this report. As the original product lot could not be determined and no original material was available, the potential for adulteration cannot be unequivocally excluded. This left our examination to determine the potential risk of an interaction.

As noted above, the only commonality in the evaluation of the 4 case reports was vitamins. This reflects the common use of these products and cannot be taken as a causal factor without further evaluation; nor does this observation preclude the involvement of other medicinal products. The findings reported here would suggest that there is a real but low to modest potential for vitamins to be the main source of this AE. 

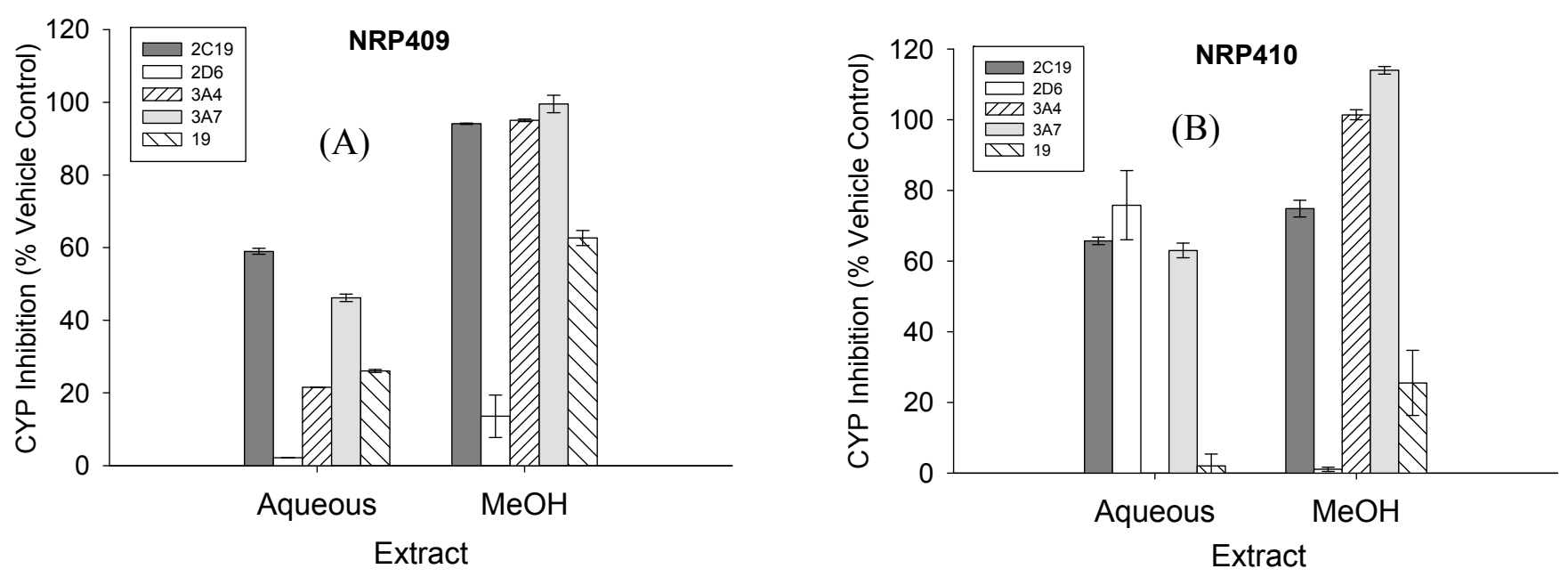

Figure 2. Effect of aqueous and methanolic extracts from (A) ThyroSense (NRP 409) and (B) femMED (NRP 410) on cytochrome P450 2C19-, 2D6-, 3A4-, 3A7-, and 19-mediated metabolism. Mean \pm SD of at least two separate tests. NRP. Nutraceutical Research Programme number.

In addition to the presence of one or more vitamins in these products, it was evident from the product labels than many of these products also contained a wide range of minerals and excipients. Some products also contained a natural health product. The excipients were presumably included as inert vehicles to facilitate formulation; however, the inertness is now being questioned as some recent studies have indicated that some excipients can markedly affect drug transport and disposition (3538). Ren et al (35) examined the effects of 22 common excipients on cytochrome P450 3A4 and found that 15 of $22(68.2 \%)$ tested excipients could inhibit the activity of CYP3A4 more than $50 \%$ in vitro, particularly the surfactants and polymers. Ren et al (36) examined four common nonionic surfactants polysorbate 20 , polyoxyl 35 castor oil, polyoxyl 40 stearate and poloxamer 188 , on cytochrome P450 3A. All surfactants inhibited midazolam 1'-hydroxylation in a concentrationdependent manner and presented a mixed competitive inhibitory model. Zhu et al. (37) investigated the effects of polyoxyethylene 40 stearate on the activity of P-glycoprotein (P-gp) and six major cytochrome P450 (CYP) isoforms. The stearate inhibited P-gp mediated efflux in a concentration-dependent manner and CYP2C9 and CYP2C19 inhibition was found to be clinically significant. Mudra and Borchardt (38) investigated the effects of polyethylene glycol (PEG) 400 (2\% or $20 \%$, v/v), D-alpha-tocopheryl polyethylene glycol-
1000 succinate (TPGS; $100 \mu \mathrm{g} / \mathrm{mL}$ ), Cremophor EL $(47.5 \mu \mathrm{g} / \mathrm{mL})$, and polysorbate (Tween) 80 (25 $\mu \mathrm{g} / \mathrm{mL}$ ) solubilizing agents on P450 (CYP) 3A and $\mathrm{P}$-glycoprotein $(\mathrm{P}-\mathrm{gp})$ in the rat intestinal mucosa. Only Tween 80 increased paracellular absorption. Rat intestinal CYP3A was significantly inhibited by PEG-400. Cremophor and TPGS increased the fraction of norverapamil in plasma, consistent with excipient-mediated inhibition of P-gp. Further studies are required to determine the extent, if any, to which excipients in the products examined in this study contributed to the inhibitory potential, but the possibility remains that there is a potential for interaction.

As the progesterone cream was compounded in a local pharmacy, there is no information on how it was compounded which would affect bioavailability (39) and thus the potential for interaction. Progesterone is a $3 \mathrm{~A} 4$ substrate where the oxidative biotransformation occurs through hydroxylation at the C16 position (40). Hence, any interaction which could affect the disposition of progesterone could increase the risk of an AE.

The results of this study clearly demonstrate that there is a potential for both NRP 409 and 410 to affect P450-mediated metabolism. None of the botanical materials in NHP 409 and 410 are known stimulants that could produce these AEs. Skullcap and Withania have sedative/adaptogen properties; Chasteberry, Saw palmetto, and wild yam are reportedly hormone modulating products; milk 
thistle is taken for liver ailments and raspberry is used as an antioxidant. Guggul which is commonly used for cholesterol management was initiated. The in vitro vitamin and NHP 409 and 410 data obtained with this study suggests that there is a potential risk for an interaction with progesterone. However, the extended therapeutic period and use of at least 3 health products confounds whether a single product was responsible for the interaction, such as NRP 410 which was the last product introduced or the interaction was a result of a sufficiently high loading effect. While the case reports and the in vitro analysis strongly suggest that a potential for interactions and affection of CYP450 enzymes is present, a clinical study would be necessary to determine the pharmacoepidemiologic impact of these findings.

Vitamin use, like that of other NHPs is not always disclosed to the health care professional. As some vitamins can have toxicity or cause serious adverse events through interaction their concurrent use with other therapeutic products should be monitored. With the exception of the two herbal products NRP 409 and 410, all of the NHPs tested had a low to moderate potential to affect CYPmediated metabolism. These two herbals had a strong inhibitory effect. The screening clearly demonstrated the in vitro potential for these products to affect CYP-mediated metabolism is variable and may be affected by the sum of their components.

Generally, the inhibitory or stimulatory effect of a product is proportional to concentration. This can then be related to the dose and rate of uptake. In this study it was noted that the products with the highest vitamin content did not have the correspondingly highest inhibitory activity. The multi-component nature of the medicinal and nonmedicinal components in these products makes it difficult to clearly rationalize effect on this basis. It may be that the event occurred as a response to the total xenobiotic loading rather than due to a single product.

The findings of this study suggest that some vitamins and $\mathrm{tBC}$ containing products examined under our conditions have the potential to affect drug metabolism and disposition. The blended herbal products NRP 409 and 410, however, have the highest potential to affect the safety and efficacy of health products. Further studies are warranted to determine whether these in vitro effects have a clinical significance.

\section{ACKNOWLEDGEMENTS}

We acknowledge the excellent technical assistance of M. Bryan, B. Chauhan, A. Franovic, N. Singhal, and J.W. Budzinski; and useful conversations with RPG van Heeswijk. This study was supported in part by the AIDS Program Committee of Ontario, APOGEE-Net, National Science and Engineering Research Council of Canada (Strategic Program), Canadian Institutes of Health Research, the Canadian Patient Safety Institute, and Health Canada. Sunita Vohra receives salary support from the Alberta Heritage Foundation for Medical Research, and the Canadian Institutes of Health Research.

\section{REFERENCES}

1. Ang-Lee, M.K., Moss, J., Yuan, C.S. Herbal medicines and perioperative care. JAMA, 11:286(2):208-216, 2001.

2. Bernstein, B.J., Grasso, T. Prevalence of complementary and alternative medicine use in cancer patients. Oncology Huntington, 15(10):1267-1272; discussion 1272-8, 1283, 2001.

3. Ernst, E. Adverse effects of herbal drugs in dermatology. Br J Dermatol, 143:923-929, 2000.

4. Gold, J.L., Laxer, D.A., Dergal, J.M., Lanctot, K.L., Rochon, P.A. Herbal-drug therapy interactions: a focus on dementia. Curr Opin Clin Nutr Metab Care, 4: 29-34, 2001.

5. Gibson, P.S., Powrie, R., Star, J. Herbal and alternative medicine use during pregnancy: a cross-sectional survey. Obstet Gynecol, 97(4 Suppl 1):S44-S45, 2001.

6. Brinker, F. Herb Contraindications and Drug Interactions, $2^{\text {nd }}$ ed. Eclectic Medical Publications, Sandy Oregon. 35, 1998.

7. Brooks, S. (ed.). Botanical Toxicology. Protocol Journal of Botanical Medicine 1(1):147-158, 1995.

8. Foster, B.C., Arnason, J.T., Briggs, C.J. Natural health products and drug disposition. Ann Rev Pharmacol Toxicol, 45:203-226, 2005.

9. Liu, G. Effects of some compounds isolated from Chinese medicinal herbs on hepatic microsomal cytochrome P-450 and their potential biological consequences. Drug Metab Rev, 23(3\&4):439-465, 1991.

10. 10 Guo, L.Q., Yamaoe, Y. Inhibition of cytochrome $\mathrm{P} 450$ by furanocoumarins in grapefruit juice and herbal medicines. Acta Pharmacol Sin, 25(2):129-136, 2004. 
11. 11 Ioannides, C. Pharmacokinetic interactions between herbal remedies and medicinal drugs. Xenobiotica, 32(6):451-478, 2002.

12. Io, A.A. Herb-drug interactions: an overview of the clinical evidence. Fundam Clin Pharmacol, 19(1):116, 2005.

13. Zhou, S., Gao, Y., Jiang, W., Huang, M., Xu, A., Paxton, J.W. Interactions of herbs with P450. Drug Metab Rev, 35(1):35-98, 2003.

14. Murty, M. Postmarket surveillance of natural health products in Canada: clinical and federal regulatory perpsectives. Can J Physiol Pharmacol, 85:952-955, 2007.

15. Charrois, T.L., Hill, R.L., Vu, D., et al. Community identification of natural health product-drug interactions. Ann Pharmacother, 41:1124-1129, 2007.

16. Chauhan, B.M., van Heeswijk, R., Bourbeau, M., et al. The effect of beta-carotene on P-glycoprotein (Pgp) and CYP 3A4 activity in-vitro (abstract). Can J Infect Dis, 16(suppl):A, 48A, 2005.

17. Rogovik, A.L., Vohra, S., Goldman, R.D. Safety considerations and potential interactions of vitamins: should vitamins be considered drugs? Ann. Pharmacother, 44, 2010. Prepublication

18. Zhang, Q.Y., Dunbar, D., Kaminsky, L. Human cytochrome P-450 metabolism of retinals to retinoic acids. Drug Metab Dispos, 28(3):292-297, 2000.

19. Marill, J., Capron, C.C., Idres, N., Chabot, G.G. Human P450s involved in the metabolism of 9-cisand 13-cis-retinoic acids. Biochem Pharmacol, 63(5):933-943, 2002.

20. Kamachi, S., Sugimoto, K., Yamasaki, T., Hirose, N., Ide, H., Ohyama, Y. Metabolic activation of 1alpha-hydroxyvitamin D3 in human liver microsomes. Xenobiotica, 31(10):701-712, 2001.

21. Ohyama, Y., Yamasaki, T. Eight P450s catalyze vitamin D metabolism. Front Biosci, 9:3007-3018, 2004.

22. Yasunami, Y., Hara, H., Iwamura, T., Kataoka, T., Adachi, T. Cjun N-terminal kinase modulates 1, 25dihydroxyvitamin D3-induced cytochrome P450 3A4 gene expression. Drug Metab Dispos, 32(7):685-688, 2004.

23. Jurutka, P.W., Thompson, P.D., Whitfield, G.K., et al. Molecular and functional comparison of 1, 25dihydroxyvitamin $\mathrm{D}(3)$ and the novel vitamin $\mathrm{D}$ receptor ligand, lithocholic acid, in activating transcription of P450 3A4. J Cell Biochem, 94(5):917-943, 2005.

24. Wang, K., Chen, S., Xie, W., Wan, Y.J. Retinoids induce P450 3A4 through RXR, VDR-mediated pathway. Biochem Pharmacol, 75(11):2204-2213, 2008.

25. Adedoyin, A., Stiff, D.D., Smith, D.C., et al. Alltrans-retinoic acid modulation of drug-metabolizing enzyme activities: investigation with selective metabolic drug probes. Cancer Chemother Pharmacol, 41(2):133-139, 1998.

26. Van Heeswijk, R.P.G., Cooper, C.L., Foster, B.C., et al. The Effect of High-dose Vitamin $\mathrm{C}$ on Hepatic CYP3A4 Activity. Pharmacother, 25(12):17251728, 1005.

27. Slain, D., Amsden, J.R., Khakoo, R.A., Fisher, M.A., Lalka, D., Hobbs, G.R. Effect of high-dose vitamin $\mathrm{C}$ on the steady-state pharmacokinetics of the protease inhibitor indinavir in healthy volunteers. Pharmacother, 25(2):165-170, 2005.

28. Foster, B.C., Foster, M.S., Vandenhoek, S., et al. An in vitro evaluation of human cytochrome P450 3A4 and P-glycoprotein inhibition by garlic. J Pharm Pharmac Sci, 4(2):176-184, 2001.

29. Tam, TW., Liu, R., Arnason, J.T., et al. Actions of ethnobotanically selected Cree anti-diabetic plants on human cytochrome P450 isoforms and flavincontaining monooxygenase 3. J Ethnopharmacol, 126:119-126, 2009.

30. Budzinski, J.W., Foster, B.C., Vandenhoek, S., Arnason, J.T. An in vitro evaluation of human cytochrome P450 3A4 inhibition by selected commercial herbal extracts and tinctures. Phytomedicine, 7(4):273-282, 2000.

31. Io, A.A., Ernst, E. Interactions between herbal medicines and prescribed drugs: a systematic review. Drugs, 61(15):2163-2175, 2001.

32. Foster, B.C., Vandenhoek, S., Hanna, J., et al. Effects of natural health products on cytochrome P450 drug metabolism. Phytomedicine, 10(4):334342, 2003.

33. Faria, A., Monteiro, R., Aevedo, I., Calhau, C. Pomegranate juice effects on cytochrome P450S expression: in vivo studies. J Med Food 2007; 10(4):643-49.

34. Hu, Z., Yang, X., Ho, P.C., et al. Herb-drug interactions: a literature review. Drugs, 65(9):12391282, 2005.

35. Ren, X., Mao, X., Si, L., Cao, L., Xiong, H., Qiu, J., Schimmer, A.D., Li, G. Pharmaceutical excipients inhibit cytochrome P450 activity in cell free systems and after systemic administration. Eur $\mathrm{J}$ Pharm Biopharm, 70(1):279-288, 2008.

36. Ren, X., Mao, X., Cao, L., et al. Nonionic surfactants are strong inhibitors of cytochrome $\mathrm{P} 450$ $3 \mathrm{~A}$ biotransformation activity in vitro and in vivo. Eur J Pharm Sci, 36(4-5):401-411, 2009.

37. Zhu, S., Huang, R., Hong, M., et al. Effects of polyoxyethylene (40) stearate on the activity of Pglycoprotein and cytochrome P450. Eur J Pharm Sci, 37(5):573-580, 2009.

38. Mudra, D.R., Borchardt, R.T. Absorption barriers in the rat intestinal mucosa. 3: Effects of polyethoxylated solubilizing agents on drug permeation and metabolism. J Pharm Sci, 99(2):1016-1027, 2010. 
39. Lopes, L.B., Murphy, N., Nornoo, A. Enhancement of transdermal delivery of progesterone using medium-chain mono and diglycerides as skin penetration enhancers. Pharm Dev Technol, 14(5):524-529, 2009.
40. Park, H., Lee, S., Suh, J. Structural and dynamical basis of broad substrate specificity, catalytic mechanism, and inhibition of cytochrome P450 3A4. J Am Chem Soc, 127(39):13634-13642, 2005.

Supplemental information for Table 4. Summary of vitamin, mineral, and excipient components listed on the product labels of the multivitamin supplements (Nutraceutical Research Programme numbers 395 to 404). All amounts are listed in mg unless otherwise indicated. -, absent; $x$, present but amount not listed.

\begin{tabular}{|c|c|c|c|c|c|c|c|c|c|c|}
\hline Ingredient & 395 & 396 & 397 & 398 & 399 & 400 & 401 & 402 & $403 \S$ & $404 \S$ \\
\hline OTHER & & & & & & & & & & \\
\hline $\begin{array}{l}\text { Green tea leaves } \\
\text { (Camellia } \\
\text { sinensis) ** }\end{array}$ & 1.875 & - & - & - & - & - & - & - & - & - \\
\hline $\begin{array}{l}\text { Ginseng (Panax } \\
\text { ginseng) (root) }\end{array}$ & - & - & - & - & 50 & - & - & - & - & - \\
\hline $\begin{array}{l}\text { Citrus } \\
\text { bioflavonoids } \\
\text { (Citrus limon, } \\
\text { rind) }\end{array}$ & - & - & - & - & - & - & - & - & 2 & 2 \\
\hline Lycopene & - & - & - & - & - & - & - & - & 0.3 & 0.3 \\
\hline $\begin{array}{l}\text { Digestive } \\
\text { enzymes }\end{array}$ & - & - & - & - & - & - & - & - & 4 & 2 \\
\hline $\begin{array}{l}\text { Peppermint } \\
\text { extract (Mentha } \\
\text { piperita, leaves) }\end{array}$ & - & - & - & - & - & - & - & - & 2 & - \\
\hline $\begin{array}{l}\text { Green tea } \\
\text { phytosome } \\
\text { (Camellia } \\
\text { sinensis, leaf; } \\
\text { Glycine max, } \\
\text { soybean) }\end{array}$ & - & - & - & - & - & - & - & - & 1 & - \\
\hline $\begin{array}{l}\text { Grape seed } \\
\text { phytosome (Vitis } \\
\text { vinifera, seeds; } \\
\text { Glycine max, } \\
\text { soybean) }\end{array}$ & - & - & - & - & - & - & - & - & 1 & - \\
\hline $\begin{array}{l}\text { Natural mixed } \\
\text { vitamin E } \\
\text { tocopherols }\end{array}$ & - & - & - & - & - & - & - & - & - & $10 \mathrm{IU}$ \\
\hline $\begin{array}{l}\text { Oleaselect (Olea } \\
\text { europaea, fruit) } \\
\text { (standardized to } \\
30 \% \text { phenols }\end{array}$ & - & - & - & - & - & - & - & - & - & 4 \\
\hline $\begin{array}{l}\text { Turmeric extract } \\
\text { (Curcuma longa, } \\
\text { stalk) }\end{array}$ & - & - & - & - & - & - & - & - & - & 2 \\
\hline $\begin{array}{l}\text { NON- } \\
\text { MEDICINAL }\end{array}$ & & & & & & & & & & \\
\hline Acacia gum & $\mathrm{x}$ & - & - & - & - & - & - & $\mathrm{x}$ & & \\
\hline $\begin{array}{l}\text { Acetylated } \\
\text { monoglycerides }\end{array}$ & $\mathrm{x}$ & - & - & - & - & - & - & - & & \\
\hline $\begin{array}{l}\text { Ascorbyl } \\
\text { palmitate }\end{array}$ & $\mathrm{x}$ & - & - & - & - & - & - & $\mathrm{x}$ & & \\
\hline
\end{tabular}




\begin{tabular}{|c|c|c|c|c|c|c|c|c|}
\hline Aspartame & - & - & - & $\mathrm{x}$ & - & - & - & - \\
\hline BHT & - & - & - & - & - & - & - & $\mathrm{x}$ \\
\hline $\begin{array}{l}\text { Calcium } \\
\text { cyclamate }\end{array}$ & - & - & - & $\mathrm{x}$ & - & - & - & - \\
\hline $\begin{array}{l}\text { Calcium } \\
\text { phosphate dibasic }\end{array}$ & $\mathrm{x}$ & $\mathrm{x}$ & - & - & - & - & - & - \\
\hline Calcium silicate & - & $\mathrm{x}$ & - & - & - & $\mathrm{x}$ & $\mathrm{x}$ & - \\
\hline Cellulose & - & - & $\mathrm{x}$ & - & - & - & - & - \\
\hline Citric acid & - & - & - & $\mathrm{x}$ & - & - & - & $\mathrm{x}$ \\
\hline $\begin{array}{l}\text { Colloidal silicon } \\
\text { dioxide }\end{array}$ & - & - & - & - & $\mathrm{x}$ & $\mathrm{x}$ & $\mathrm{x}$ & - \\
\hline Corn starch & $\mathrm{x}$ & - & - & - & - & - & - & $\mathrm{x}$ \\
\hline $\begin{array}{l}\text { Croscarmellose } \\
\text { sodium }\end{array}$ & $\mathrm{x}$ & $\mathrm{x}$ & $\mathrm{x}$ & - & $\mathrm{x}$ & $\mathrm{x}$ & $\mathrm{x}$ & $\mathrm{x}$ \\
\hline Crospovidone & $\mathrm{x}$ & - & - & - & - & - & - & $\mathrm{x}$ \\
\hline $\begin{array}{l}\text { Dextrose } \\
\text { monohydrate }\end{array}$ & $\mathrm{x}$ & - & - & - & - & - & - & - \\
\hline $\begin{array}{l}\text { Dicalcium } \\
\text { phosphate }\end{array}$ & - & - & - & - & - & - & - & $\mathrm{x}$ \\
\hline $\begin{array}{l}\text { dl-alpha- } \\
\text { tocopheryl } \\
\text { acetate }\end{array}$ & $\mathrm{x}$ & - & - & - & - & - & - & - \\
\hline EDTA & - & - & $\mathrm{x}$ & - & - & - & - & - \\
\hline Ethanol & $\mathrm{x}$ & - & - & - & - & - & - & - \\
\hline Gelatin & $\mathrm{x}$ & - & - & - & $\mathrm{x}$ & $\mathrm{x}$ & $\mathrm{x}$ & $\mathrm{x}$ \\
\hline $\begin{array}{l}\text { Hydrogenated } \\
\text { soybean oil }\end{array}$ & $\mathrm{x}$ & - & - & - & - & - & - & $\mathrm{x}$ \\
\hline $\begin{array}{l}\text { Hydrolyzed } \\
\text { polyvinyl alcohol }\end{array}$ & - & - & - & - & $\mathrm{x}$ & - & - & - \\
\hline $\begin{array}{l}\text { Hydroxypropyl } \\
\text { methylcellulose }\end{array}$ & - & $\mathrm{x}$ & - & - & $\mathrm{x}$ & - & - & - \\
\hline $\begin{array}{l}\text { Hydroxypropylce } \\
\text { llulose }\end{array}$ & $\mathrm{x}$ & - & - & - & - & - & - & - \\
\hline $\begin{array}{l}\text { Hydroxypropyl } \\
\text { methylcellulose }\end{array}$ & - & - & $\mathrm{x}$ & - & - & - & - & - \\
\hline Hypromellose & $\mathrm{x}$ & - & - & - & - & - & - & $\mathrm{x}$ \\
\hline Isopropyl alcohol & $\mathrm{x}$ & - & - & - & - & - & - & - \\
\hline Lactose & - & - & - & - & - & - & - & $\mathrm{x}$ \\
\hline $\begin{array}{l}\text { Magnesium } \\
\text { sterate }\end{array}$ & $\mathrm{x}$ & $\mathrm{x}$ & $\mathrm{x}$ & $\mathrm{x}$ & $\mathrm{x}$ & $\mathrm{x}$ & $\mathrm{x}$ & $\mathrm{x}$ \\
\hline Malic acid & - & - & - & $\mathrm{x}$ & - & - & - & - \\
\hline Maltodextrin & $\mathrm{x}$ & - & - & - & - & - & - & $\mathrm{x}$ \\
\hline $\begin{array}{l}\text { Medium chain } \\
\text { triglycerides }\end{array}$ & - & - & - & - & - & - & - & $\mathrm{x}$ \\
\hline Methylcellulose & $\mathrm{x}$ & - & - & - & - & - & - & $\mathrm{x}$ \\
\hline Methyl paraben & - & - & $\mathrm{x}$ & - & - & - & - & - \\
\hline $\begin{array}{l}\text { Microcrystalline } \\
\text { cellulose }\end{array}$ & $\mathrm{x}$ & $\mathrm{x}$ & - & - & $\mathrm{x}$ & $\mathrm{x}$ & $\mathrm{x}$ & $\mathrm{x}$ \\
\hline Mineral oil & - & - & - & - & - & - & - & $\mathrm{x}$ \\
\hline $\begin{array}{l}\text { Modified food } \\
\text { starch }\end{array}$ & - & - & - & - & - & - & - & $\mathrm{x}$ \\
\hline $\begin{array}{l}\text { Monoester: } \\
\text { propylene glycol } \\
\text { and glycerol }\end{array}$ & - & - & - & $\mathrm{x}$ & - & - & - & - \\
\hline $\begin{array}{l}\text { Natural and } \\
\text { artificial flavours }\end{array}$ & - & - & - & $\mathrm{x}$ & - & - & - & - \\
\hline Partially & - & - & - & - & - & $\mathrm{x}$ & $\mathrm{x}$ & - \\
\hline
\end{tabular}




\begin{tabular}{|c|c|c|c|c|c|c|c|c|}
\hline $\begin{array}{l}\text { hydrolyzed } \\
\text { polyvinyl alcohol }\end{array}$ & & & & & & & & \\
\hline Polydextrose & $\mathrm{x}$ & - & - & - & - & - & - & $\mathrm{x}$ \\
\hline $\begin{array}{l}\text { Polyethylene } \\
\text { glycol }\end{array}$ & $\mathrm{x}$ & $\mathrm{x}$ & $\mathrm{x}$ & - & $\mathrm{x}$ & $\mathrm{x}$ & $\mathrm{x}$ & - \\
\hline Polysorbate & - & - & - & - & - & - & - & $\mathrm{x}$ \\
\hline Povidone & $\mathrm{x}$ & $\mathrm{x}$ & $\mathrm{x}$ & $\mathrm{x}$ & $\mathrm{x}$ & - & - & - \\
\hline Propyl paraben & - & - & $\mathrm{x}$ & - & - & - & - & - \\
\hline Purified water & $\mathrm{x}$ & - & - & - & - & - & - & - \\
\hline Shellac glaze & $\mathrm{x}$ & - & - & - & - & - & - & - \\
\hline Silicon dioxide & $\mathrm{x}$ & $\mathrm{x}$ & $\mathrm{x}$ & - & - & - & - & $\mathrm{x}$ \\
\hline Sodium ascorbate & $\mathrm{x}$ & - & - & - & - & - & - & $\mathrm{x}$ \\
\hline Sodium benzoate & - & - & - & - & - & - & - & $\mathrm{x}$ \\
\hline Sodium citrate & - & - & - & - & - & - & - & $\mathrm{x}$ \\
\hline $\begin{array}{l}\text { Sodium lauryl } \\
\text { sulfate }\end{array}$ & - & - & - & - & - & - & - & $\mathrm{x}$ \\
\hline Sorbic acid & - & - & - & - & - & - & - & $\mathrm{x}$ \\
\hline Sorbitol & - & - & - & $\mathrm{x}$ & - & - & - & - \\
\hline Soya lecithin & - & - & - & - & - & - & $\mathrm{x}$ & - \\
\hline Stearic acid & $\mathrm{x}$ & - & $\mathrm{x}$ & - & - & - & - & $\mathrm{x}$ \\
\hline Sucrose & $\mathrm{x}$ & - & - & - & - & - & - & $\mathrm{x}$ \\
\hline Sugar & - & $\mathrm{x}$ & $\mathrm{x}$ & $\mathrm{x}$ & $\mathrm{x}$ & - & - & - \\
\hline Talc & - & - & - & - & $\mathrm{x}$ & $\mathrm{x}$ & $\mathrm{x}$ & $\mathrm{x}$ \\
\hline Tartrazine & - & - & - & - & - & $\mathrm{x}$ & - & - \\
\hline Titanium dioxide & $\mathrm{x}$ & $\mathrm{x}$ & $\mathrm{x}$ & - & $\mathrm{x}$ & $\mathrm{x}$ & $\mathrm{x}$ & $\mathrm{x}$ \\
\hline Triacetin & $\mathrm{x}$ & - & - & - & - & - & - & - \\
\hline $\begin{array}{l}\text { Tricalcium } \\
\text { phosphate }\end{array}$ & $\mathrm{x}$ & - & - & - & - & - & - & - \\
\hline Triethyl citrate & - & - & - & - & - & - & - & $\mathrm{x}$ \\
\hline $\begin{array}{l}\text { Allura red AC } \\
\text { aluminum lake }\end{array}$ & - & - & - & - & $\mathrm{x}$ & - & - & - \\
\hline $\begin{array}{l}\text { D\&C yellow No. } \\
10\end{array}$ & $\mathrm{x}$ & $\mathrm{x}$ & - & - & - & - & - & - \\
\hline FD\&C blue No. 1 & $\mathrm{x}$ & - & - & - & - & - & - & - \\
\hline FD\&C blue No. 2 & - & - & - & $\mathrm{x}$ & - & - & - & - \\
\hline FD\&C red No. 40 & $\mathrm{x}$ & - & - & - & - & - & - & - \\
\hline FD\&C red No. 3 & - & - & - & $\mathrm{x}$ & - & - & - & - \\
\hline $\begin{array}{l}\text { FD\&C yellow } \\
\text { No. } 6\end{array}$ & - & $\mathrm{x}$ & - & $\mathrm{x}$ & - & - & - & $\mathrm{x}$ \\
\hline $\begin{array}{l}\text { Indigo carmine } \\
\text { aluminum lake }\end{array}$ & - & - & - & - & $\mathrm{x}$ & - & - & - \\
\hline Red iron oxide & - & - & $\mathrm{x}$ & - & - & - & - & - \\
\hline $\begin{array}{l}\text { Sunset Yellow } \\
\text { FCF aluminum } \\
\text { lake }\end{array}$ & - & - & - & - & $\mathrm{x}$ & $\mathrm{x}$ & $\mathrm{x}$ & - \\
\hline $\begin{array}{l}\text { Yellow iron } \\
\text { oxide }\end{array}$ & - & - & $\mathrm{x}$ & - & - & - & - & - \\
\hline
\end{tabular}

